\title{
Study on current status and future trends of commercial poultry production in Pakistan
}

\author{
Tahir Hameed, Tauseef Muhammad Asmat, Muhammad Masood Tariq, \\ Masroor Ahmad Bajwa, Majed Rafeeq, Babar Hilal, Muhammad \\ Adnan Attique and Farhat Abbas Bokhari \\ Center for Advanced Studies in Vaccinology and Biotechnology, University of Balochistan, Quetta-Pakistan \\ *Corresponding author's email: farhatabbas2005@gmail.com \\ Citation \\ Tahir Hameed,Tauseef Muhammad Asmat, Muhammad Masood Tariq, Masroor Ahmad Bajwa, Majed Rafeeq, \\ Babar Hilal, Adnan Attique and Farhat Abbas Bokhari. Study on current status and future trends of commercial \\ poultry production in Pakistan. Pure and Applied Biology. Vol. 6, Issue 1, pp190-196. \\ http://dx.doi.org/10.19045/bspab.2017.60013
}

\begin{tabular}{llll}
\hline Received: 02/11/2016 & Revised: 31/01/2017 & Accepted: 06/02/2017 & Online First: 07/02/2017
\end{tabular}

\section{Abstract}

The study was designed to analyze the present status and predict the future trends of poultry production in Pakistan. This project focused on poultry price fluctuation during last ten years. On the basis of that data, we predicted the future trends for poultry price in Pakistan. The layer population, in commercial farms has shown a marked increase from 9.55 million birds during the year 1995 to 27.50 million birds in year 2010. The broiler production from 72.80 million birds in the year 1991 to 795 million birds in the year 2010 was recorded which led to increased broiler meat production. During the year 1995, almost 111772 metric tons of broiler meat was produced which increased to 587000 metric tons during the year 2010. Although the broiler production was increased significantly but price of broiler meat also kept increasing which demonstrate the shortfall in demand and supply. In case of layer flocks same trend was observed. In spite of significant increase in layer flocks which led to enhanced egg production, still the egg price kept rising during all the previous years. The regression models were used for prediction of layer, broiler, egg and poultry meat production on the basis of past 15-20year's production.

Keywords: Commercial poultry; Broiler; Layer; Future trends; Pakistan

\section{Introduction}

In poultry sector, population index growth is about $10-12 \%$ and it contributes a lion share $(40 \%)$ of meat produced in Pakistan. Moreover, poultry sector consumes agriculture products and bi-products in the form of poultry feed ingredients which provide almost Rs.50 billion rupees/year revenue to agriculture sector. In Pakistan, there are 400 hatcheries, 150 feed mills, 8.5 million broiler breeders farms, 0.428 million-layer breeders and total feed consumption by poultry is 5.51 million metric tons [1]. Although in Pakistan, the concept of commercial poultry rearing, hatching and feed mills were not known before 1960s. Poultry feed is considered as the major expenses in poultry production as its share is around $60-70 \%$ of total costs. Obviously, the major fraction of feed costs is its ingredients used and feed processing/ 
preparing costs [2]. Modernization in poultry rearing techniques and controlled housing system has already changed the trends of poultry production in recent years. To maximize the profit not only efficient poultry raring, management on scientific basis is required but it's also critical to keep constant eye on costs and production index. Aside from prevalent market prices of various poultry goods, variability in cost components is mainly dependent on feed efficiency and managerial conditions [2-4]. Better planning and management and minimizing the effects of environment also help to reduce the production cost $[5,6]$.

Keeping this in view, the present study was conducted with the objective of making analytical evaluation of relationship between poultry population and production of the poultry products in Pakistan. Defined production systems which are based on animal/human friendly relation, to the animals housed. Adaptation of modern scientific advances in poultry raring contributes to the enhanced and high quality products $[7,8]$.

This study deciphered the past, present and future trends of poultry production in Pakistan.

\section{Materials and methods}

Study was designed to forecast and evaluate the future trends in commercial poultry, its price/population index and regression model $\&$ regression analysis of broiler production versus ' $\mathrm{X}$ ' egg produced.

Detailed information regarding broiler, layer and breeder stock population, their production capabilities and price characteristics were collected. Moreover data regarding feeding, breeding, management, egg production, costs against vaccination/medicine and constrains of poultry production were collected and analyzed statically. The data was obtained from record books of concerned district poultry officers, public and private sector farms. Variables measured during study include sex of day old chick, its live bodyweight and biometric measurements, which were recorded randomly in breeder farms [8]. The information about egg production was recorded regularly on farm record register. For comparative study the data for the years1991to 2010 was collected from PRI Rawalpindi after an official permission and poultry population data was composed in this study.

\section{Results}

\section{Layer population during 1991-2011}

Data regarding layer production in Pakistan since 1991 to 2011 was collected and analyzed satistically (Table 1). Data showed a constant increaase in layer production in each consective year. During the year 1991, total 9.55 Million birds were raised and almost increased to $300 \%$ during the year 2011. This dipicts a significant increase in layer farming and showed a constant increase in demand.

Once the data regading pooultry production in Pakistan since 1991 to 2011 was collected and analyzed, it became easier to predict the future trend of poultry farming and its production as shown in Table 2. The predicted value in million heads is shown in Table 9. Future trend forecast showed a value of 19.96 million layers in the year 2011 and 26.99 million layers in the year 2020. The law of demand and suplly governs everywhere and has significat effect on price. Other factors such as disease out breaks, management etc also play a critical role in poultry production. The season also played an important role in the consumption of meat and farmers have to plan accordingly to market their poultry in winter and rainy seasons. This factor predicts the farmers to start fresh batch of poultry to fetch good market price during these particular seasons [9]. Keeping all other factor as constant, this estimation will play a key role in analysis of poultry production growth index and its future trends specially the projected population. 
Table 1. Layer production for last 20 years (million birds) at the commercial poultry farms

\begin{tabular}{|c|c|c|c|}
\hline Years & $\begin{array}{l}\text { Number of layers at farms } \\
\text { (million birds) }\end{array}$ & Years & $\begin{array}{l}\text { Number of layers at farms } \\
\text { (million birds) }\end{array}$ \\
\hline 1991 & 9.55 & 2002 & 17.50 \\
\hline 1992 & 10.85 & 2003 & 19.56 \\
\hline 1993 & 9.22 & 2004 & 19.60 \\
\hline 1994 & 9.56 & 2005 & 19.60 \\
\hline 1995 & 9.60 & 2006 & 20.06 \\
\hline 1996 & 9.60 & 2007 & 21.70 \\
\hline 1997 & 10.06 & 2008 & 24.00 \\
\hline 1998 & 11.70 & 2009 & 26.00 \\
\hline 1999 & 14.00 & 2010 & 25.00 \\
\hline 2000 & 16.00 & 2011 & 27.50 \\
\hline 2001 & 15.00 & & \\
\hline
\end{tabular}

Table 2. Regression model to predict the layer production in Pakistan

\begin{tabular}{|l|l|l|l|l|}
\hline Predictor & Co-efficient & S.E & T & P-value \\
\hline Constant & 8.01 & 0.8533 & 9.40 & 0.0001 \\
\hline $\mathbf{X}$ & 0.703 & 0.1314 & 5.35 & 0.0003 \\
\hline
\end{tabular}

\section{Egg production}

The egg production data from 1991 to 2011 was collected and analyzed statistically. The results showed a marked increased as the egg production more than doubled in 2011 as compared to 1991 as shown in Table 3. For future prediction of egg production at the commercial layer farms, the regression models were employed on the basis of last 20 years egg production trend (Table 4 ). The value 83.41 shows the average increase the egg produced during each calendar year. As regression value indicates that $83.41 \%$ of the variation of the egg production was associated with the independent variable (years). The estimated coefficients suggested significant impact of independent variable (years) on the egg production. The estimated number of egg produced is also shown in Table 9.

Table 3. Egg production for last 20 years (million birds) at the commercial poultry farms

\begin{tabular}{|c|c|c|c|}
\hline Years & $\begin{array}{c}\text { Number of eggs produced } \\
\text { (million eggs) }\end{array}$ & Years & $\begin{array}{c}\text { No. of eggs produced } \\
\text { (million eggs) }\end{array}$ \\
\hline 1991 & $2,101.00$ & 2002 & $3,160.00$ \\
\hline 1992 & $2,390.00$ & 2003 & $4,101.00$ \\
\hline 1993 & $2,031.00$ & 2004 & $4,390.00$ \\
\hline 1994 & $2,106.00$ & 2005 & 4231.00 \\
\hline 1995 & $2,200.00$ & 2006 & $4,106.00$ \\
\hline 1996 & $2,200.00$ & 2007 & $4,200.00$ \\
\hline 1997 & $2,305.00$ & 2008 & $4,200.00$ \\
\hline 1998 & $2,680.77$ & 2009 & $4,305.00$ \\
\hline 1999 & $3,150.00$ & 2010 & $4,680.77$ \\
\hline 2000 & $2,317.00$ & 2011 & $5,150.00$ \\
\hline 2001 & $2,772.00$ & & \\
\hline
\end{tabular}


Table 4. Prediction of egg production

\begin{tabular}{|l|l|l|l|l|}
\hline Predictor & Co-efficient & S.E & T & P-value \\
\hline Constant & 1992.3 & 147.6 & 13.50 & 0.00001 \\
\hline X & 83.41 & 22.73 & 3.67 & 0.0004 \\
\hline
\end{tabular}

\section{Broiler production}

To meet the need of poultry meat, the broiler produced from 1991 to 2011 are shown in Table 5. Similar trend in broiler production was observed as was documented in layer and egg production during the last several years. This constant development and increased production in all poultry sectors demonstrates a surge in demand. To predict the broiler production at the commercial poultry farms, the regression models were used on the basis of last 20 years population. The Table 6 shows the co-efficient of regression model of Boiler Production on different time periods. This also shows the co-efficient of Production of Boiler is significant because its p-value is 0.0001 which is less than 0.05 . The value 33.146 shows the average increase in the Production of Boiler during each year. As $\mathrm{R}$ value indicates that $33.146 \%$ of the variation of the broiler production was due to the effect of the independent variable (years). The estimated coefficients demonstrate the significant impact of independent variable (years) on the broiler production. From the model one can predict the type and magnitude of the change in broiler production in the study area. The predicted number of broilers produced till 2020 are also shown in Table 9.

Table 5. Broiler production for last 20 years (million birds) at the commercial poultry farms

\begin{tabular}{|l|l|l|l|}
\hline Years & $\begin{array}{l}\text { Number of broilers at farms } \\
\text { (million birds) }\end{array}$ & Years & $\begin{array}{l}\text { Number of broilers at } \\
\text { farms } \\
\text { (million birds) }\end{array}$ \\
\hline 1991 & 72.80 & 2002 & 495.00 \\
\hline 1992 & 160.00 & 2003 & 508.00 \\
\hline 1993 & 144.00 & 2004 & 549.00 \\
\hline 1994 & 208.00 & 2005 & 583.50 \\
\hline 1995 & 249.00 & 2006 & 662.00 \\
\hline 1996 & 283.50 & 2007 & 620.00 \\
\hline 1997 & 162.00 & 2008 & 680.00 \\
\hline 1998 & 220.00 & 2009 & 740.00 \\
\hline 1999 & 280.00 & 2010 & 728.00 \\
\hline 2000 & 340.00 & 2011 & 795.00 \\
\hline 2001 & 528.00 & & \\
\hline
\end{tabular}

Table 6. Prediction of broiler production

\begin{tabular}{|l|l|l|l|l|}
\hline Predictor & Co-efficient & S.E & T & P-value \\
\hline Constant & 79.56 & 38.31 & 2.08 & 0.065 \\
\hline $\mathbf{X}$ & 33.146 & 5.90 & 5.62 & 0.0001 \\
\hline
\end{tabular}

\section{Chicken meat production}

Chicken meat production at the commercially developed poultry farms in the study area indicated a considerable increase from 111772 metric tons in the year 1991 to 587000 metric tons in the year 2011 
(Table 7). The forecast of chicken meat production for next 10 years at the commercial poultry farms developed through regression models on the basis of chicken meat production trend for last 20 years. The predicted number of broilers meat production till 2020 are shown in Table 9.

The Table 8 shows the co-efficient of regression model of chicken meat production on different time periods. This also shows the co-efficient of chicken meat production is significant because its $p$-value is 0.0001 which is less than 0.05 . The value 23353 shows the average increase in chicken meat production at every one year. The regression value suggested a variation of 23353 tons in chicken meat production with change of each year (independent variable). The estimated coefficients suggested significant impact of years on the increase in chick meat production at commercial poultry farms.

If the production declines or remains static, ultimately price hike is expected in accordance with the application of demand /supply rule [10-12]. Previously, it has been demonstrated that management decisions at hatcheries as well as breeder farms affect wholesale rates of eggs and broiler rate per $\mathrm{kg}$ $[13,14]$. Moreover, flock age, egg weight on hatching, egg characteristics, fertility, hatchability and sale-able chick production had significant effect on poultry products market rate [15-17].

Table 7. Chicken meat production for last 20 years (million birds) at the commercial poultry farms

\begin{tabular}{|l|l|l|l|}
\hline Years & $\begin{array}{l}\text { Chicken meat obtained } \\
\text { (metric tons) }\end{array}$ & Years & $\begin{array}{l}\text { Chicken meat obtained } \\
\text { (metric tons) }\end{array}$ \\
\hline 1991 & $111,772.00$ & 2002 & $460,000.00$ \\
\hline 1992 & $160,000.00$ & 2003 & $411,772.00$ \\
\hline 1993 & $144,000.00$ & 2004 & $460,000.00$ \\
\hline 1994 & $208,000.00$ & 2005 & $447,000.00$ \\
\hline 1995 & $249,000.00$ & 2006 & $509,000.00$ \\
\hline 1996 & $283,500.00$ & 2007 & $549,000.00$ \\
\hline 1997 & $162,000.00$ & 2008 & $583,500.00$ \\
\hline 1998 & $220,000.00$ & 2009 & $562,000.00$ \\
\hline 1999 & $280,000.00$ & 2010 & $520,000.00$ \\
\hline 2000 & $340,000.00$ & 2011 & $587,000.00$ \\
\hline 2001 & $405,000.00$ & & \\
\hline
\end{tabular}

Table 8. Prediction of broiler meat production

\begin{tabular}{|l|l|l|l|l|}
\hline Predictor & Co-efficient & S.E & T & P-value \\
\hline Constant & 116830 & 25262 & 4.62 & 0.001 \\
\hline X & 23353 & 3890 & 6.00 & 0.0001 \\
\hline
\end{tabular}


Table 9. Future trend of number of broiler layer, eggs and poultry meat in Pakistan

\begin{tabular}{|l|l|c|c|c|}
\hline & $\begin{array}{l}\text { Layers population in } \\
\text { million number } \\
\text { future trend forecast } \\
\mathbf{y = 8 . 0 1 + 0 . 7 0 3 x}\end{array}$ & $\begin{array}{l}\text { Broiler population in } \\
\text { million number } \\
\text { future trend forecast } \\
\mathbf{y = 7 9 . 5 6 + 3 3 . 1 4 6 x}\end{array}$ & $\begin{array}{l}\text { Egg production in } \\
\text { million numbers } \\
\text { future trends forecast } \\
\text { y=992.3+83.41x }\end{array}$ & $\begin{array}{l}\text { Production of } \\
\text { meat 000 tons } \\
\text { future trend } \\
\text { y=11680+23353x }\end{array}$ \\
\hline Year & Forecast & Forecast & Forecast & Forecast \\
\hline $\mathbf{2 0 1 1}$ & 19.961 & 642.94 & 3410.27 & 408681 \\
$\mathbf{2 0 1 2}$ & 20.664 & 676.08 & 3493.68 & 432034 \\
$\mathbf{2 0 1 3}$ & 21.367 & 709.22 & 3577.09 & 455387 \\
$\mathbf{2 0 1 4}$ & 22.07 & 742.36 & 3660.50 & 478740 \\
$\mathbf{2 0 1 5}$ & 22.773 & 775.5 & 3743.91 & 502093 \\
$\mathbf{2 0 1 6}$ & 23.476 & 808.64 & 3827.32 & 525446 \\
$\mathbf{2 0 1 7}$ & 24.882 & 874.92 & 3994.14 & 572152 \\
$\mathbf{2 0 1 8}$ & 25.585 & 908.06 & 4077.55 & 595505 \\
$\mathbf{2 0 1 9}$ & 26.288 & 941.2 & 4160.96 & 618858 \\
$\mathbf{2 0 2 0}$ & 26.991 & 974.34 & 4244.37 & 642211 \\
\hline
\end{tabular}

\section{Conclusion}

This study will assist to evaluate the future requirements and to determine the growth levels of poultry sector in Pakistan. It will also help to enhance quantitative productions to meet the future demands of poultry products in Pakistan.

\section{Authors' contributions}

Conceived and designed the experiments: $\mathrm{T}$ Hameed, MA Bajwa \& FA Bukhari, Performed the experiments: T Hameed \& M Rafeeq. Analyzed the data: B Hilal, MA Attique \& MM Tariq, Wrote the paper: T Hameed, TM Asmat \& FA Bokhari.

\section{References}

1. Pakistan poultry association. (PPA, 201112) Ipex Magazine of Expo 2011, page 5.souvinier.

2. Farooq M, Main MA \& Asher A (2001). Factors affecting cost of production and net profit per broiler in the tropics. Journal of Livestock Reserves for Rural Development 13: 11-16.

3. Zahir-ud-Din, Farooq M, Durrani FR, Chand N \& Ahmed J (2001). Status of broilers produced in Swat, Pakistan. Livestock Research for Rural Development 13(3): 67-71.

4. Elwardany A, Sherif MBT, Enab AA, Abdel-Sami AM, Marai IFM \& Metwally
MK (1998). Some performance traits and abdominal fat contents of three Egyptian indigenous laying breeds. First international conference on animal production and health in semi-arid areas, El-Aris. September 1-3, pp. 471-481.

5. Zaghari M, Fazlali F, Gerami A, Eila N \& Moradi S (2011). Effects of environmental factors on the performance of broiler breeder hens. J Appl Poult Res 20 (3): 383-389.

6. Ayieko DM, Bett EK \& Kabuage LW (2014). Analysis of collective action: The Case of indigenous chicken farmers from Makueni County, Kenya. International Journal of Agricultural Extension 2(2): 137-145.

7. Sundrum A (2001). Organic livestock farming. A critical Review. Livestock Production Science 67 (3) : 207-215.

8. Behnke KC \& Beyer RS (2004). Effect of feed processing on broiler performance. $\mathrm{Ph} . \mathrm{D}$ Dissertation, Kansas State University, Manhattan, USA.

9. Suther OP (2007). Consumption patterns of poultry products in Hyderabad. M.Sc. Thesis (Poultry Husbandry) Sindh Agriculture University Tandojam, Pp. 1-68.

10. Mendes AS, Gudoski DC, Cargnelutti AF, Silva EJ, Carvalho EH \& Morello GM 
(2014). Factors that impact the financial performance of broiler production in southern states of Paraná, Brazil. Revista Brasileira de Ciência Avícola 16(1): 113119. https://dx.doi.org/10.1590/S1516635X2014000100016.

11. Silva IJO \& Vieira FMC (2010). Ambiência animal e as perdas produtivas no manejo pré-abate: o caso da avicultura de corte brasileira. Archivos de Zootecnia 59: 113131.

12. Dongre Pritee (2015). Economic analysis of broiler production in Balaghat district of Madhya Pradesh. Thesis. Available at: http://krishikosh.egranth.ac.in/handle/1/676 29

13. Raju DT \& Suryanarayana MVAN (2005). Meat consumption in Prakasam district of Andhra Pradesh: an analysis. Livestock
Research for Rural Development 17(130): 1-8.

14. Abebaw D \& Haile M (2013). The impact of cooperatives on agricultural technology adoption: Empirical evidence from Ethiopia. Food Policy 38: 82-91.

15. Yassin H, Velthuis AGJ, Boerjan M, Riel JW \& Huirne RBM (2008). Field study on broiler eggs Hatchibilty. Poultry Science 87: 2408-2417.

16. Ulmer-Franco AM, Fasenko GM \& Christopher EE (2010). Hatching egg characteristics, chick quality, and broiler performance at 2 breeder flock ages and from 3 egg weights. Poultry Science 89 (12): 2735-42.

17. Jiang X, Groen AF \& Brascamp EW (1998). Economic values in broiler breeding. $J$ of Poultry Science Jul; 77(7): 934-43. 